\title{
RESPON SISWA TERHADAP SOAL MATEMATIKA MIRIP PISA DENGAN KONTEKS BERINTEGRASI NILAI ISLAM
}

\author{
Moch. Lutfianto ${ }^{1}$, Anisa Fatwa Sari ${ }^{2}$ \\ ${ }^{1,2}$ STKIP Al Hikmah Surabaya \\ lutfi@hikmahuniversity.ac.id
}

\begin{abstract}
Abstrak
Soal PISA merupakan soal yang didasarkan pada permasalahan nyata dalam kehidupan. Konteks soal dalam PISA dapat menggunakan integrasi nilai-nilai Islam. Tujuan penelitian ini adalah untuk mengetahui efek dari pemberian soal matematika mirip PISA terhadap siswa setelah mengerjakan soal tersebut. Penelitian ini merupakan penelitian kualitatif. Siswa diberikan soal model PISA yang telah didesain dengan konteks integrasi nilai-nilai Islam. Dari hasil pengerjaan soal siswa diberikan angket dan wawancara terkait dengan efek soal yang telah dikerjakan. Penelitian ini menghasilkan bahwa $100 \%$ siswa merasa lebih termotivasi dalam beramal Islami karena mengetahui manfaat dari konteks yang ada di soal yang diujikan. Mayoritas siswa baru mengetahui bahwa ada pahala yang besar dalam amal Islami yang pernah dilakukan. Sebagian besar siswa merasa soalnya cukup sulit dan aneh akan tetapi siswa merasa senang karena aktivitas amal islami yang pernah dilakukan ternyata mendapatkan pahala. Simpulan dari penelitian ini adalah dengan pemberian soal matematika mirip PISA maka dapat meningkatkan amal Islami siswa dalam kehidupan sehari-hari.
\end{abstract}

Kata kunci: Soal Matematika, PISA, Integrasi Nilai-nilai Islam

\begin{abstract}
PISA problems are based on real life context. It can be also enriched with Islamic value integration. The aim of this reseacrh is understanding the effect of posing PISA-like problems to students. The research was carried out qualitatively. The problems which are designed with context of Islamic value integration was posed to students. Then, the students filled in a questionare and have been interviewed about their responses on the problems. The results show that all subject being more motivated in doing a good deed suit on Islamic values. They told that they gained new understanding upon Islamic values from the context presented in the problems. They became aware that they will get reward when they practice an Islamic teaching. Some of them think that the problems are quite difficult and even unfamiliar for them. In the other hand, they feel happy because they finally know that the practice of Islamic teaching their doing so far will be rewarded.
\end{abstract}

Key words: Mathematical Problem, PISA, Islamic Value Integration

\section{PENDAHULUAN}

Kehidupan abad 21 menuntut kualitas sumber daya manusia yang berbeda dari generasi sebelumnya. Keterampilan mekanistik sudah digantikan oleh teknologi seperti mesin dan komputer. Sumber daya manusia saat ini lebih dituntut memiliki keterampilan berpikir kritis, kreatif, kolaboratif, komunikatif, serta cakap dalam mengambil keputusan. Kecapakan 
tersebut dibutuhkan untuk mengelola, mengolah dan merespon arus informasi dan pemutakhiran teknologi yang cepat.

Pendidikan adalah kunci penyiapan sumber daya manusia. Secara formal, pendidikan sekolah memberikan kesempatan siswa untuk mengembangkan potensi dan mengasah kecakapan yang dibutuhkan di masa mendatang. Matematika berkontribusi pada pengembangan logika berpikir dan penalaran siswa. Proses berpikir melibatkan kemampuan berpikir kritis, kreatif, dan mengkomunikasikan gagasan melalui model matematika. Hal ini sesuai dengan fungsi mata pelajaran matematika berdasarkan kurikulum tahun 2006.

Tahap pendidikan melibatkan proses evaluasi untuk mengukur capaian belajar sesuai tujuan yang diharapkan. Salah satu bentuk pengukuran keterampilan matematika siswa adalah penilaian proses penalaran siswa. Siswa diberikan masalah matematika non rutin untuk mengevaluasi kemampuan pemecahan masalah, penalaran matematis, ataupun komunikasi matematika. Proses evaluasi tersebut menuntut instrumen pengukuran berupa soal matematika. Sebagian besar instrumen dikembangkan mengggunakan kerangka kerja (framework) yang mengacu pada model (Program for International Student Assessment) PISA. Soal matematika bermodel PISA digunakan untuk mengukur penalaran matematis siswa, komunikasi matematis, serta pemecahan masalah siswa (Anisah, Zulkardi, \& Darmawijoyo, 2013; Mardhiyanti, Ilma, Kesumawati, 2013; Silva, Zulkardi, Darmawijoyo, 2013; Sari, 2015).

PISA menggunakan permasalahan konteks (real world problem) sebagai pijakan dalam menyajikan soal. Soal PISA merupakan soal yang dapat mengasah siswa untuk bisa memahami konsep matematika murni dan penggunaanya dalam menjelajahi permasalahan dalam kehidupan (Lutfianto, 2013; OECD, 2010). Beberapa negara termasuk Indonesia menggunakan penilaian PISA untuk mengetahui perkembangan siswanya. Indonesia mulai mengikuti PISA sejak tahun 2000 (OECD, 2016; Stacey, 2011).

Pada penilaian terakhir tahun 2015 Indonesia masih tetap berada pada peringkat bawah jika dibandingkan dengan negara-negara yang ada di ASEAN yang mengikuti penilaian PISA yakni Thailand, Vietnam dan Singapura. Di bidang matematika Indonesia mendapatkan nilai 386. Peringkat 63 dari 70 peserta PISA (OECD, 2016). Peringkat Indonesia mendorong penelitian bertema PISA baik dari segi hasil maupun proses PISA yang melibatkan soal termasuk matematika. Sebagian besar penelitian bertujuan mengembangkan soal mirip PISA sebagai referensi soal bagi siswa Indonesia.

Pengembangan soal PISA mengacu pada penilaian yang disebut dengan Framework (kerangka kerja). Framework PISA dikeluarkan sebelum proses penilaian dilakukan sehingga 
negara peserta tes dapat mempersiapkan dengan baik dalam penilaian. Pada framework PISA terdapat 3 domain utama yakni konteks, konten dan kompetensi (OECD, 2016). Beberapa pengembangan soal matematika model PISA berbasis pada domain konten. Konten tentang uncertainty dan quantity dipilih sebagai pokok bahasan soal (Mardhiyanti dkk., 2013; Silva dkk., 2013).

Adapun konteks PISA berada pada ranah permasalahan kehidupan memberikan ruang bagi siswa untuk mendapatkan pengetahuan dalam mengerjakan soal tersebut (Fensham, 2009). Konteks PISA tidak hanya mengukur kemampuan matematika tetapi menilai kemampuan berpikir kritis. PISA memberikan kesempatan siswa untuk berpikir kritis terhadap situasi yang disajikan dalam soal.

Melalui konteks, siswa dapat mengenal situasi nyata ataupun model yang terkait kehidupan sehari-hari. Soal PISA yang kontekstual juga dapat menimbulkan motivasi dalam kehidupan sehari-hari. Ketika siswa mengetahui manfaat dari soal yang dikerjakan maka siswa akan lebih tertarik dalam pengaplikasian soal dalam kehidupan. Hal ini seperti yang disampaikan oleh Freudenthal yang memandang mathematics as human activity (de Corte, 1996; Gravemeijer, 1994; Freudenthal, 1968).

Konteks tentu memuat nilai-nilai sosial dari situasi kehidupan yang dikaitkan pada masalah matematika. Siswa di Indonesia mendapatkan soal yang sedikit berbeda dari segi penyajian konteks dari siswa di negara lain. Hal ini dilakukan agar siswa dapat memahami situasi dalam konteks dengan lebih baik. Lebih lanjut, pengembangan soal PISA sudah mulai dilakukan pada ranah domain konteks. Konteks yang termuat dalam soal model PISA tidak hanya disusun 'dekat' dengan siswa tetapi juga memuat nilai-nilai tertentu.

Salah satu nilai yang dapat diintegrasikan dalam pembelajaran adalah nilai Islam (Asiyanti, 2003; Nugroho, 2013). Sehingga memberikan peluang bagi siswa untuk lebih termotivasi terkait dengan tingkah laku, perbuatan atau amal islami yang biasa dilakukan dalam kehidupan sehari-hari. Soal mirip PISA juga dapat dikembangkan dengan mengintegrasikan nilai Islam ke dalam konteks soal (Lutfianto, 2016). Artikel ini menyajikan respon siswa terhadap soal matematika mirip PISA dengan konteks berintegrasi nilai Islam.

\section{METODE}

Jenis penelitian ini adalah penelitian kualitatif dengan peneliti sebagai instrumen utama penelitian. Jenis penelitian sesuai dengan tujuan penelitian yaitu mendeskripsikan respon siswa terhadap soal matematika mirip PISA dengan konteks berintegrasi nilai-nilai Islam. 
Subjek penelitian ini adalah siswa kelas IX dari sekolah berbasis Islam di Sidoarjo dan Surabaya. Sepuluh siswa berasal dari sekolah tidak berasrama dan 30 siswa berada pada sekolah berasrama.

Teknik pengambilan data dilakukan dengan pemberian tes, angket, serta wawancara. Siswa diberikan soal-soal yang telah didesain yakni soal mirip PISA dengan integrasi nilainilai Islam. Soal terdiri dari 15 macam dengan tiap soal memiliki level yang berbeda beda serta konteks integrasi nilai islam yang berbeda pula. Berikut ini adalah tabel soal mirip PISA yang diberikan:

Tabel 1. Soal Mirip PISA

\begin{tabular}{clc}
\hline No & \multicolumn{1}{c}{ Konteks Integrasi } & Jumlah \\
\hline 1 & Soal yang berhubungan dengan Hadist & 5 \\
2 & Soal yang berhubungan dengan ayat Al & 2 \\
& Quran & \\
3 & Soal dari sirah Nabi & 1 \\
4 & Soal dari kejadian sehari-hari & 7 \\
\hline & Total & 15 \\
\hline
\end{tabular}

Subjek yang terpilih diminta untuk mengerjakan soal yang telah didesain kemudian dilanjutkan dengan pemberian angket. Untuk lebih menguatkan data yang didapat maka dilakukan wawancara dari beberapa siswa yang diambil secara acak. Instrumen soal yang dipakai sebelumnya telah dinyatakan valid dan reliabel sesuai dengan tahapan penelitian pengembangan yang telah dilakukan (Lutfianto, 2016).

Hasil dari pengerjaan soal, angket dan wawancara kemudian dianalisis dengan menggunakan tahapan analisis penelitian kualitatif yakni reduksi data, penyajian data dan penarikan kesimpulan dari data yang dianalisis (Miles \& Huberman, 1994).

\section{HASIL PENELITIAN DAN PEMBAHASAN}

Subjek yang terpilih diberikan soal matematika mirip PISA dengan integrasi nilai-nilai Islam. Setelah pengerjaan soal siswa diberikan angket tentang manfaat soal yang telah dikerjakan. Angket berisikan pertanyaan untuk mengetahui apakah soal yang diberikan menambah wawasan/pengetahuan subjek tentang Islam. Selain itu angket memuat pertanyaan apakah soal yang telah dikerjakan memotivasi subjek untuk lebih mengamalkan Islam dalam kehidupan.

Dari kedua pertanyaan tesebut didapatkan Hasil angket siswa yang sekolah Islam non boarding (non asrama) didapati tabel berikut: 
Tabel 2. Respon siswa non asrama

\begin{tabular}{lccc}
\hline No & Ya & Sedang & Tidak \\
\hline 1 & 5 & 4 & 1 \\
2 & 3 & 7 & 0 \\
\hline
\end{tabular}

Dari Tabel 2. dapat diketahui bahwa 90\% siswa menyatakan bahwa soal memberikan tambahan wawasan/pengetahuan tentang Islam dan hanya ada 10\% yang menyatakan sebaliknya. Sedangkan pada pertanyaan nomor 2, siswa berpendapat bahwa $100 \%$ soal-soal yang diberikan memberikan motivasi bagi siswa untuk lebih mengamalkan pada kehidupan sehari-hari. Tidak adanya siswa yang menyatakan tidak memberikan motivasi dalam mengamalkan konteks yang ada pada soal menunjukkan soal dapat memberikan manfaat positif dalam meningkatkan amal Islami siswa meskipun siswa tidak berada pada lingkungan pondok/asrama. Temuan ini menarik untuk dikaji lebih lanjut dengan melibatkan jumlah subjek yang lebih banyak. Pertanyaan angket dapat dikembangkan lebih mendetail untuk menggali lebih jauh hubungan atau pengaruh penyajian konteks berintegrasi nilai Islam terhadap motivasi siswa.

Pada tabel berikut disajikan respon siswa yang bersekolah di sekolah berasrama. Subjek tinggal di pondok setelah pulang dari sekolah. Hasil respon dapat dilihat pada Tabel 3 dibawah ini:

Tabel 3. Siswa berasrama/pondok

\begin{tabular}{cccc}
\hline No & Ya & Sedang & Tidak \\
\hline 1 & 18 & 8 & 4 \\
2 & 14 & 16 & 0 \\
\hline
\end{tabular}

Dari tabel di atas dapat diketahui bahwa $86,7 \%$ siswa menyatakan bahwa soal yang diberikan dapat menambah wawsan/pengetahuan tentang Islam. Hal ini cukup menarik dikarenakan siswa belajar di sekolah yang berbasis Islam dan sudah sering mendapatkan pengetahuan tentang Islam. Sedangkan dari pertanyaan ke 2 didapatkan bahwa 100\% siswa lebih termotivasi dalam beramal Islami dalam keseharian.

Dari data Tabel 2 dan Tabel 3, dapat diketahui bahwa siswa yang berada pada sekolah berasrama maupun sekolah non asrama hampir 98\% merasa bahwa mereka mendapatkan pengetahuan baru tentang islam dari soal-soal yang telah dikerjakan. Soal tersebut menambah pengetahuan mereka tentang keislaman. Hasil lebih khusus didapatkan pada pertanyaan no 2 yang menunjukkan bahwa tidak ada perbedaan dalam hal soal dapat memberikan motivasi kepada siswa untuk lebih mengamalkan keislaman meskipun yang menjawab dengan tegas 
"ya" 39\% dan siswanya 61\% cukup memberikan motivasi lebih dan tidak ada yang tidak menjawab tidak memberikan motivasi.

Subjek yang dipilih untuk diwawancarai adalah subjek yang memberikan respon positif yaitu sedang atau ya. Dua subjek dipilih dari siswa non asrama dan 6 siswa dari sekolah berasrama. Berikut ini disajikan transkrip wawancara peneliti (P) kepada siswa dari sekolah non asrama (SN1) yang menjawab yang memberikan jawaban YA.

$P \quad$ : "Bagaimana soal yang kamu kerjakan tadi?"

SN1 : "Soalnya cukup sulit dan membingungkan"

$P \quad$ : "oh begitu, mungkin karena belum terbiasa ya. Apakah soal yang kamu kerjakan menurutmu berbanfaat bagi kamu?"

SN1 : "ya, cukup bermanfaat."

$P \quad$ : “apa saja manfaat yang bisa kamu rasakan secara langsung?

SN1 : "saya bisa mengetahui bahwa beberapa amalan yang telah saya lakukan ternyata memiliki hitungan pahala yang jelas. Saya juga baru tahu bahwa pahala yang saya dapatkan jika melakukan amalan itu seperti berangkat ke masjid, beriktikaf ketika ramadhan memiliki pahala yang sangat besar sekali, dan dapat dihitung dengan tepat."

$P \quad$ : apakah pengetahuan ini baru bagi kamu atau biasa saja?

SN1 : untuk soal yang dikerjakan merupakan hal baru akan tetapi untuk isi dari soal, ada beberapa yang sudah pernah tahu dan ada beberapa yang baru tahu.

$P \quad$ : apa yang menurut kamu menarik dari soal-soal yang diberikan atau kesan setelah mengerjakan soal tersebut?

SN1 : saya baru tahu ternyata soal-soal matematika bisa berhubungan dengan keislaman.

Dari penggalan wawancara di atas dapat diketahui bahwa subjek SN1 sudah mengetahui beberapa konteks keislaman yang disajikan. SN1 menyatakan bahwa salah satu manfaat yang didapatkan setelah mengerjakan soal adalah tambahan informasi keislaman. Secara spesifik subjek menjelaskan tentang kegiatan berangkat ke masjid atai i'tikaf di bulan Ramadhan. SN1 merujuk pada konteks pemberian pahala. Adapun SN1 cukup terkesan karena ternyata matematika dapat dihubungkan dengan keislaman.

Selain informatif, konteks yang disajikan juga menggugah motivasi siswa. Konteks mendapat pahala memberikan dorongan untuk beramal. Hal ini juga berlaku pada konteks ancaman. Soal yang tersaji pada Gambar 1 memuat konteks ancaman jika meninggalkan amal Islami. Ketika siswa selesai menghitung panas asli yang ada di bumi ternyata bisa membayangkan bahwa neraka memilki panas yang luar biasa yang lebih dari panasnya 
matahari. Konteks perbandingan panas menimbulkan kesadaran bahwa ancaman yang diberikan menakutkan.

Nabi Muhammad SAW mengingatkan kepada segenap manusia bahwa panas air api di Neraka lebih panas dibandingkan api di dunia. Beliau bersabda:

Artinya: "Panas api yang kamu nyalakan di dunia ini (termasuk matahari) hanyalah sepertujuh puluh dari panasnya api Neraka di akhirat. Kalau sebagian kecil (api neraka) jatuh ke dunia, niscaya mendidihlah air laut karena panasnya." (HR. Muslim)

Neraka diperuntukkan kepada orang-orang yang meninggalkan sholat, zakat, puasa ramadhan, durhaka kepada orang tua, meminum khamribi, berjudi, membunuh makhluk yang diharamkan Alah, dan sebagainya. Jika diketahui suhu pada matahari:

\begin{tabular}{|c|c|}
\hline Bagian Matahari & Suhu \\
\hline Inti & $1,5 \times 10^{70} \mathrm{Kelvin}$ \\
\hline Korona & $5 \times 10^{60} \mathrm{Kelvin}$ \\
\hline
\end{tabular}

Berapakah kiranya panas suhu (dalam Celsius) Neraka yang digunakan untuk menyiksa orang-orang yang ingkar terhadap perintah Allah SWT? $\left(x^{\circ}\right.$ Kelvin $=x-272^{\circ}$ Celsius $)$

Gambar 1. Soal no 3 tentang panas api neraka

Pada soal di Gambar 2 siswa termotivasi karena mendapatkan pengetahuan bahwa kehidupan di dunia itu hanya sementara hanya hitungan menit, tidak sampai ke jam. Sehingga mereka lebih termotivasi dalam beramal untuk bekal kehidupan di akhirat.

Allah SWT berfirman kepada semesta alam dalam Al Qur'an surat As-Sajdah ayat ke-5,

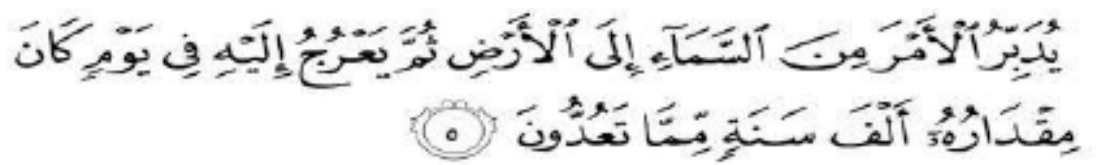

Artinya: "Dia mengatur urusan dari langit ke bumi, kemudian (urusan) itu naik kepada-Nya dalam satu hari yang kadarnya adalah seribu tahun menurut perhitunganmu."

Subhanallah, begitulah kekuasaan-Nya. Sehari di akhirat setara dengan seribu tahun di dunia. Jika ratarata usia umat Nabi Muhammad SAW adalah 63 tahun, setara dengan berapa usia tersebut di akhirat?

Gambar 2. Soal tentang waktu hidup di dunia dan akhirat

Hasil wawancara tersebut tidak berbeda dengan hasil wawancara dari siswa sekolah berasrama. Mereka juga merasa lebih termotivasi dan beramal Islami setelah mengerjakan soal tersebut.

Adapun bagi siswa yang merespon angket dengan jawaban SEDANG, hasil wawancara yang dilakukan oleh peneilit (P) dijelaskan dalam transkrip berikut.

$P \quad$ : "Bagaimana soal yang kamu kerjakan tadi?" 
SA1 : "Soalnya cukup sulit dan menyusahkan perhitungannya”

P : "oh, begitu. Trus kamu paham soal yang kamu kerjakan."

SAl : "sebenarnya paham akan tetapi soalnya susah, hitungannya banyak, waktunya kurang"

$P \quad$ : "wah, kurang banyak ya waktunyanya, terus apakah kamu mendapatkan wawasan atau pengetahuan baru dari mengerjakan soal tesebut?"

SA1 : "ya, saya mendapatkan hal baru dari soal”

$P \quad$ : "apakah itu dapat memberikan motivasi kamu?"

SAl : "motivasi apa?"

P : : "motivasi untuk lebih berbuat baik, atau melakukan amalan-amalan baik yang lain."

SA1 : "ya ada yang memberikan motivasi ada yang biasa saja."

Dari transkrip wawancara di atas dapat diketahui bahwa tingkat motivasi siswa yang menjawab sedang cukup sesuai. Mereka cenderung masih belum mantap/yakin bahwa soal tesebut dapat memberikan motivasi baginya. Ketika peneliti mencoba untuk memberikan pertanyaan tambahan pada soal tentang panas neraka, berikut transkrip hasil wawancaranya.

$P \quad$ : "bagaimana soal tentang panas neraka? Apakah kamu bisa menemukan jawabannya?"

SA1 : "belum selesai"

$P \quad$ : baik, kamu tahu berapa derajat panas air mendidih? Terus bagaimana rasanya jika tersentuh

SA1 : " $100{ }^{\circ} \mathrm{C}$, ya panas pak."

$P \quad$ : "terus bagaimana dengan panas matahari?"

SAl : "mestinya puanas pak"

P : " "terus berapa derajat, lihat pangkat dari bilangan 10 itu saja”

SA1 : "oh iya pak, jadi panas sekali ya, sampai berjuta-juta”

P : : "kalo dari hadist itu sampai tujuh kali loh panas di neraka."

SA1 : "iya, jadi di neraka bisa tambah panas sekali ya."

$P \quad$ : "trus kamu kuat di neraka"

SA1 : "ya g kuat lah pak, pinginnya di surga"

$P \quad$ : "baik, jadi apakah soal tersebut berrmanfaat bagi kamu?, apakah motivasi kamu untuk beramal baikjadi nambah?"

SA1 : "iya pak, jadi lebih semangat supaya tidak terhindar dari siswa api neraka” 
Dari hasil wawancara tambahan tentang neraka menunjukan bahwa ketidakmampuan siswa dalam mengerjakan soal ternyata dapat mengurangi keyakinan mereka atau rasa motivasi mereka dalam mengerjakan amal Islami.

\section{SIMPULAN DAN SARAN}

Dari hasil penelitian ini dapat disimpulkan bahwa soal matematika mirip PISA dengan konteks yang ada integrasi nilai-nilai Islam dapat meningkatkan motivasi siswa dalam beramal Islami sampai mendekati 100\%. Beberapa pengetahuan baru terkait dengan amalan yang sudah dilakukan juga semakin menambah keinginan untuk lebih serius dalam mengerjakan amalan tersebut. Mayoritas siswa baru mengetahui bahwa ada pahala yang dapat dihitungkan dari amalan yang dilakukan dan soal yang dikerjakan tergolong sulit dan baru bagi siswa.

Saran bagi peneliti selanjutnya jika mengunakan penelitian serupa dapat menggunakan durasi waktu yang lebih lama setelah mengerjakan soal dan dihitung persentasi peningkatan amal islami dari sebelum diberikan soal dan setelah diberikan soal.

Motivasi dan respon positif dalam penelitian ini dapat dijadikan landasan penelitian berikutnya. Angket dapat dikembangkan lebih mendalam serta dilengkapi dengan wawancara yang lebih komprehensif. Data dapat diperkaya untuk ditarik kesimpulan dengan cara memperbanyak jumlah subjek yang diberikan soal mirip PISA dengan konteks berintegrasi nilai Islam.

\section{Ucapan Terima Kasih}

Penelitian ini tidak bisa berjalan dengan baik tanpa ada sumbangsih dari di berbagai pihak. Oleh karenanya peneliti mengucapkan terimakasih kepada Kemristekdikti yang mendanai penelitian ini, sekolah SMP Al Hikmah dan SMPIT Darul Fikri sebagai tempat penelitian serta mahasiswa yang ikut membantu dalam pelaksanaan penelitian ini.

\section{DAFTAR PUSTAKA}

Anisah, A., Zulkardi, Z., \& Darmawijoyo, D. (2013). Pengembangan Soal Matematika Model PISA Pada Konten Quantity untuk Mengukur Kemampuan Penalaran Matematis Siswa Sekolah Menengah Pertama. Jurnal Pendidikan Matematika, 5(1).

Asiyanti, N. (2003). Integrasi Nilai-nilai Ajaran Islam dalam Mata Pelajaran IPA di SDIT Luqman Hakim Yogyakarta. 
De Corte, E., Greer, B., \& Verschaffel, L. (1996). Mathematics teaching and learning. In D.C. Berliner \& R. Calfee (Eds.), The handbook of educational psychology (pp.491-549). New York: Macmillan.

Fensham, P. J. (2009). Real world contexts in PISA science: Implications for context-based science education. Journal of research in science teaching, 46(8), 884-896.

Freudenthal, H. (1968). Why to teach mathematics so as to be useful. Educational studies in mathematics, 1(1), 3-8.

Gravemeijer, K. (1994). Educational development and developmental research in mathematics education. Journal for research in Mathematics Education, 443-471.

Lutfianto, M., Zulkardi, \& Hartono, Y. (2013). Unfinished Student Answer In PISA Mathematics. IndoMS - Journal on Mathematics Education, 4(2), 188-193.

Mardhiyanti, D., Ilma, R., \& Kesumawati, N. (2013). Pengembangan Soal Matematika Model PISA untuk Mengukur Kemampuan Komunikasi Matematis Siswa Sekolah Dasar. Jurnal Pendidikan Matematika, 5(1).

Miles, M. B., \& Huberman, A. M. (1994). Qualitative data analysis: An expanded sourcebook. Beverly Hills: Sage Publications.

Nugroho, f. D. (2013). Pengaruh penggunaan media film edukasi kimia berwawasan integrasi islam-sains pada materi reaksi kimia untuk smp/mts kelas vii terhadap motivasi dan prestasi belajar peserta didik di mtsn sumber agung kecamatan jetis kabupaten bantuL (Doctoral dissertation, UIN SUNAN KALIJAGA)

OECD (2016). PISA 2015 Assessment and Analytical Framework: Science, Reading, Mathematic and Financial Literacy, PISA, OECD Publishing, Paris.

OECD. (2010). PISA 2012 Mathematical Framework. Paris: OECD.

Sari, E. (2015). Pengembangan Soal Matematika Model PISA untuk Mengetahui Argumentasi Siswa di Sekolah Menengah Pertama. Jurnal Pendidikan Matematika, $9(2), 124-147$.

Silva, E., Zulkardi, Z., \& Darmawijoyo, D. (2013). Pengembangan Soal Matematika Model PISA Pada Konten Uncertainty untuk Mengukur Kemampuan Pemecahan Masalah Matematika Siswa Sekolah Menengah Pertama. Jurnal Pendidikan Matematika, 5(1).

Stacey, K. (2011). The PISA View of Mathematical Literacy in Indonesia. IndoMS - Journal on Mathematics Education, 2(2), 95-126. 